\title{
RESENHA \\ Uma Antologia para o patrimônio edificado
}

\author{
Ana Lúcia de Abreu Gomes ${ }^{1 *}$ \\ Universidade de Brasília
}

\begin{abstract}
Choay (20II) permanece fiel às suas origens. Como historiadora das teorias e formas urbanas e professora emérita da Universidade de Paris VIII, nossa autora tem-se dedicado a refletir acerca das questões que envolvem o patrimônio edificado, o patrimônio material. A despeito das mudanças ocorridas nesse campo e sua mais recente inflexão em direção à imaterialidade, ela adverte seus leitores nas linhas iniciais de seu mais recente trabalho de combate: trata-se do patrimônio de pedra e cal, da monumentalidade do patrimônio.

O tipo de questionamento presente no título? ${ }^{2}$ Aquele que se pergunta acerca dos usos sociais do patrimônio na densidade da relação da construção do espaço urbano das cidades e metrópoles pelos homens, aprofundando as dimensões política e social da tarefa de ocupação desses espaços; aquele que indaga, igualmente, pelos usos e significados do espaço construído em sua dimensão antropológica. $E$, ainda, mais do que perscrutar acerca da relação que devemos manter com o passado, Françoise Choay nos põe diante do futuro: para nossa autora, a questão do patrimônio não se expressa em uma relação exclusiva com o já vivido, mas, sim, numa relação com o devir.
\end{abstract}

Ainda sobre o título, nossa autora esclarece o motivo pelo qual trata de um combate. Desde a publicação, em 1992, do clássico "Alegoria do Patrimônio" em França, houve muitas mudanças no campo do patrimônio, inclusive aquelas decorrentes do recrudescimento da mundialização do conceito e das práticas a ele relacionadas, esvaziando o campo do patrimônio da materialidade e da densidade características de suas origens. À medida que a noção de patrimônio se amplia, a categoria monumento se enfraquece; à medida que $\circ$ presente rapidamente deve se tornar passado, em sua obsolescência, - patrimônio não só se torna musealizável, mas se torna, igualmente, passível de comercialização, numa alusão explícita à afirmação de Karl Marx de que o capitalismo transforma tudo, inclusive o tempo, em mercadoria ${ }^{3}$.

Sendo assim, nossa autora nos propõe três frentes de combate: a da formação/educação, que visaria oferecer a todos os franceses uma introdução às artes, à arquitetura e ao urbanismo; a da reutilização desses lugares de memória, única forma, segundo sua interpretação, de se evitar a musealização desses espaços e, por fim, retomar as relações entre o universal e o singular,

\footnotetext{
I *Ana Lúcia de Abreu Gomes é formada em História pela Universidade Federal Fluminense. Desenvolveu mestrado em História Social na Universidade Federal do Rio de Janeiro e doutorado em História Cultural na Universidade de Brasília. Durante 20 anos lecionou História para o Ensino Fundamental e Médio, atuando, inclusive na área de Ensino de Jovens e Adultos. Também atuou como técnica em História do Instituto do Patrimônio Histórico e Artístico Nacional no Departamento do Patrimônio Imaterial. Atualmente é professora adjunta do Curso de Museologia da Faculdade de Ciência da Informação da Universidade de Brasília, ministrando aulas na área de patrimônio.
}

2 Choay (20II).

3 Ver sobre o tema: Hartog (2006). 
o global e o local, possibilitando a sobrevivência da diversidade uma vez que reinsere a comunidade em seu tempo e espaço próprios.

$\mathrm{Na}$ metodologia de apresentação do tema, nossa autora reitera a opção por ser professora sempre: como em suas aulas presenciais, ela nos propõe leituras seminais de autores que viveram e participaram efetivamente das questões e debates do patrimônio na sequência de uma introdução que expõe teoricamente o objeto de estudo em questão. Essa antologia de textos, selecionada por ela, remete o leitor à compreensão das inflexões no conceito de monumento, monumento histórico, patrimônio, recuperando a historicidade dos usos diferenciados desses vocábulos. A seleção variada de textos e documentos recupera elementos relacionados ao papel memorial da arquitetura e das comunidades de antiquários; destaca, igualmente, os elementos que, em França, possibilitaram a constituição de um campo para a preservação do patrimônio, dentre eles a elaboração dos preceitos teóricos que orientaram as intervenções nos monumentos, que formaram um corpo de profissionais dedicados ao restauro, que possibilitaram a constituição de um corpus legislativo para a proteção de monumentos e obras de arte e que, por fim, estabeleceram uma ação precípua do Estado francês sobre o campo.

Tal seleção de textos que compõem essa antologia não se restringe, entretanto, ao período revolucionário francês; ela chega ao século $X X$, recuperando a importância das Cartas de Atenas e Veneza, assim como apresenta ao leitor as inflexões promovidas pela Unesco no campo de estudo em tela.

O presente livro, portanto, se encontra organizado, didaticamente, em duas partes: uma primeira, denominada Introdução, oportunidade em que a autora traz as questões teóricas que, nas últimas décadas, têm envolvido o campo; em seguida, uma segunda parte, a antologia propriamente dita, resultado da seleção de textos emblemáticos que contemplam diferentes períodos históricos, notadamente dos séculos XIl ao XX. Cada um desses textos vem acompanhado de uma pequena informação acerca de seu autor e de seu protagonismo para o estudo que se pretende desenvolver.

Na Introdução, a autora dá relevância à experiência do patrimônio nas sociedades ocidentais européias, recuperando a interpretação de Alois Riegl sobre a distinção entre os termos monumento e monumento histórico. Segundo nossa autora, as revoluções culturais do Renascimento e aquela concernente à Segunda Revolução Industrial teriam sido responsáveis por fundir essas duas noções na palavra patrimônio. Não se trata apenas de uma perda semântica, mas, principalmente, de uma perda da densidade da diferença entre essas experiências.

Ainda segundo nossa autora, no decorrer desse processo, essa experiência europeia e ocidental - a do patrimônio - ganhou novos adjetivos que a acompanham e definem: patrimônio material, cultural, natural, econômico dentre outras, mas todas elas categorias usadas pelos ocidentais para caracterizar e analisar sua própria experiência histórica e social. Aqui, nossa autora apresenta a complexidade da questão ao elencar mais um elemento à sua análise: o alargamento da concepção de patrimônio a partir do momento que essa experiência atingiu outros países e culturas e seus desdobramentos em relação ao próprio patrimônio europeu num processo claro de retroalimentação.

Sobre a questão do patrimônio como experiência europeia, José Reginaldo Rodrigues no texto "O Patrimônio como Categoria de Pensamento"4

4 Gonçalves (2009). 
assinala que este não é uma invenção moderna, europeia e ocidental; essa experiência é característica de inúmeras sociedades e que a Modernidade Ocidental europeia lhe imprimiu contornos semânticos muito específicos; portanto, estaríamos lidando com uma categoria de pensamento, e, em sendo assim, não restrita ao continente europeu.

A despeito disso, como as experiências são distintas, Rodrigues se pergunta acerca da possibilidade de se transitar, por meio dessa categoria, entre mundos sociais, culturais e temporais diversos. Num ponto de convergência entre esses autores, José Reginaldo reitera a posição de Françoise Choay: há que se definir com clareza os contornos semânticos que o vocábulo patrimônio assume e, para tal, nossa autora preenche com a densidade histórica e a experiência social esses contornos no interior da Europa, procurando dar a conhecer a riqueza, a ambivalência dessa experiência que hoje tem sido interpelada pela presença de outros patrimônios. Dizendo de outra maneira, a Europa em sua trajetória histórica, veio incorporando uma série de culturas a sua própria história e é justamente na ampliação da temática para outros horizontes, outras culturas, outras formas de pensar e abordar o patrimônio que Françoise Choay se volta para a experiência europeia como se ela nos perguntasse: do que mesmo estamos falando? De que patrimônio estamos nos referindo?

Nessa linha de argumentação, ela reforça a dimensão material dessa categoria de pensamento e o momento em que esse discurso emerge na Europa, com a distinção entre monumento e monumento histórico, estabelecida pelo historiador da arte Aloïs Riegl. Enquanto o monumento é algo vivo, presente na memória da comunidade à qual ele se direciona, o monumento histórico é estabelecido segundo um critério temporal e estético.

Para aqueles que acompanham os escritos e as reflexões de nossa autora, compreende-se perfeitamente a questão: trata-se de recuperar as clivagens existentes em termos lexicais: patrimônio edificado, patrimônio histórico, monumento, monumento histórico, reiterando sua opção pela arquitetura feita, edificada por homens não apenas em sua relação com o espaço, como a princípio poderia pensar um leitor mais afoito, mas, principalmente, em relação ao tempo.Trata-se de fazer compreender a significação do ato construtivo onde o tempo deve repousar, deve se sedimentar para daí formar cultura.

Ao se perguntar acerca do patrimônio edificado, Françoise Choay nos mostra uma forma diversa das sociedades lidarem com o tempo; com a temporalidade e com a constituição de seu patrimônio: não essa urgência de passado, que nos interpela o tempo todo, não essa dimensão econômica do patrimônio, que vem se adensando mais e mais.

\section{Referências}

CHOAY, Françoise. O patrimônio em questão: antologia para um combate. Belo Horizonte: Fino Traço, 201 I.

GONÇALVES, José Reginaldo dos Santos. O patrimônio como categoria de pensamento. In:ABREU, Regina; CHAGAS, Mario. Memória e patrimônio: ensaios contemporâneos. Rio de Janeiro: Lamparina, 2009.

HARTOG, François. Tempo e patrimônio.VARIAHISTORIA, Belo Horizonte, v. 22, n. 36, p. 26I-273, jul./dez. 2006. 